Brit. J. vener. Dis. (1961), 37, 270.

\title{
THERAPY OF LYMPHOGRANULOMA INGUINALE WITH 17,025*
}

BY

\author{
C. D. ALERGANT \\ Royal Infirmary, Liverpool
}

The search for effective anti-viral agents continues in many laboratories in a number of countries. A clinical trial of 7218 (2:3 dimethyl quinoxaline dioxide) in lymphogranuloma inguinale 8 years ago (Alergant, 1953) showed that although the drug was therapeutically active, toxic side-effects prevented its being regarded as a useful addition to the pharmacopoeia. Although of no value in the treatment of lymphogranuloma it is interesting to note that, despite its potential toxicity, it shows promise in quite an unexpected field, as a life-saving drug in antibiotic-resistant $P$ s. pyocyanea infections.

Hurst and Hull (1961) working in the laboratory which produced 7218 (Hurst, Landquist, Melvin, Peters, Senior, Silk, and Stacey, 1953) have recently described the anti-viral activity of a newly synthesized compound, provisionally termed 17,025 (5 methoxy carbonyl - 6 methyl - $4-(5$ - nitrofuryl) 2 - oxy $1: 2: 3: 4$ : tetrahydropyrimidine), against infections with viruses of the psittacosis-lymphogranuloma-trachoma group both in mice and in the developing chick embryo. They made an exhaustive comparison of its activity in relation to antibiotics and to other synthetic compounds known to act against these viruses, and they found the compound equally active against two strains of psittacosis, two of lymphogranuloma, three of trachoma, and two of inclusion blennorrhoea. The drug was essentially non-toxic and, when injected intramuscularly, produced no immediate or delayed ill-effects. Although weight for weight only a tenth or a twentieth as active as aureomycin, its very sparing solubility brings it into the category of a repository drug; in favourable circumstances a single injection of a suspension in arachis oil was found to be capable of controlling completely a virulent psittacosis infection in a majority of mice.

\footnotetext{
* Paper read at the M.S.S.V.D. meeting in Paris on May 12, 1961
}

Inferring that 17,025 might be a useful drug in cases of lymphogranuloma inguinale for which infrequent parenteral therapy rather than daily oral treatment was desirable, its effects have been investigated in man.

\section{Material}

The present small series of nine patients comprises all cases of lymphogranuloma inguinale admitted to the wards at Newsham General Hospital, Liverpool, during the 6 months July, 1960, to January, 1961 (Table I, opposite).

All were adult male seafarers suffering from inguinal and/or femoral buboes. Their ages ranged from 22 to 33 years; four were European, three Indian, one a Brazilian, and one West African, and all had acquired the infection outside the United Kingdom-in India (4 cases), in Brazil ( 2 cases), and in South Africa, West Africa, and the West Indies ( 1 case each).

The lymph gland enlargement was right-sided in four cases, left-sided in two cases, and bilateral in the remaining three. In seven patients both the Frei test and the lymphogranuloma inguinale complement-fixation tests were positive; one had a positive Frei test and a negative complement-fixation test, and one patient in whom the diagnosis was made entirely on clinical grounds had, nevertheless, a repeatedly negative Frei and complement-fixation tests.

Three patients had received previous treatment, but in no case was treatment started with 17,025 until it was clear that the clinical condition was stationary.

\section{Dosage and Administration}

The compound was supplied in rubber-capped vials containing $4 \mathrm{ml}$. of a 25 per cent. suspension in arachis oil. Of a consistency similar to P.A.M. it passed readily through a No. 1 serum needle although it was found convenient to use a larger needle when filling the syringe. Intramuscular injection into the gluteal muscles produced no more discomfort than a comparable volume of P.A.M. 
TABLE I

CLINICAL PARTICULARS OF NINE CASES OF LYMPHOGRANULOMA INGUINALE

\begin{tabular}{|c|c|c|c|c|c|c|c|c|c|c|c|}
\hline $\begin{array}{l}\text { Case } \\
\text { No. }\end{array}$ & $\begin{array}{c}\text { Age } \\
\text { (yrs) }\end{array}$ & Nationality & $\begin{array}{l}\text { Source of } \\
\text { Infection }\end{array}$ & $\begin{array}{c}\text { Glandular } \\
\text { Enlargement }\end{array}$ & $\begin{array}{l}\text { Deep } \\
\text { Glands } \\
\text { Affected }\end{array}$ & $\begin{array}{c}\text { Frei } \\
\text { Re- } \\
\text { action }\end{array}$ & $\begin{array}{c}\text { Complement- } \\
\text { Fixation } \\
\text { Test }\end{array}$ & $\begin{array}{c}\text { Previous } \\
\text { Treat- } \\
\text { ment }\end{array}$ & $\underset{\text { Dotal }}{\stackrel{\text { Tosage }}{\text { Dosage }}}$ & $\begin{array}{c}\text { Clinical } \\
\text { Result }\end{array}$ & $\begin{array}{c}\text { Subsequent } \\
\text { Treatment }\end{array}$ \\
\hline 1 & 26 & Brazilian & Brazil & Right & No & + & $1 / 80$ & No & 2 & Good & \\
\hline 2 & 23 & Norwegian & W. Africa & Right & No & + & $1 / 40$ & Yes & 4 & Good & \\
\hline 3 & 24 & British & India & Left & Yes & + & $1 / 160$ & No & 4 and 8 & $\begin{array}{l}\text { Good } \\
\text { Relapse }\end{array}$ & Terramycin \\
\hline 4 & 28 & Indian & India & $\begin{array}{c}\text { Right and } \\
\text { Left }\end{array}$ & No & + & $1 / 160$ & Yes & 4 & Excellent & \\
\hline 5 & 25 & Norwegian & W. Indies & Left & No & - & - & No & 5 & Very Good & \\
\hline 6 & 26 & Indian & India & $\begin{array}{c}\text { Right and } \\
\text { Left }\end{array}$ & No & $\therefore$ & $1 / 160$ & No & 6 & Excellent & \\
\hline 7 & 22 & British & Brazil & $\begin{array}{c}\text { Right and } \\
\text { Left }\end{array}$ & No & + & $1 / 160$ & No & 9 and 8 & $\begin{array}{l}\text { Good } \\
\text { Relapse }\end{array}$ & \\
\hline 8 & 27 & Indian & India & Right & No & + & - & Yes & 6 & Excellent & \\
\hline 9 & 33 & W. African & S. Africa & Right & No & + & $1 / 20$ & No & 10 & Fair & Terramycin \\
\hline
\end{tabular}

The initial dosage was low $(0.5 \mathrm{~g}$. weekly), but when the drug proved to be well tolerated the dosage was increased in subsequent cases, the last four patients all being given $2 \mathrm{~g}$. twice weekly. The total dosage varied between 2 and $10 \mathrm{~g}$.

Side-Effects. - There were no complaints of pain at the injection site and no side-effects of any kind were noted. White cell counts were carried out before and after treatment on a number of patients but in no case was any change noted.

Absorption and Excretion.-Duncan (1960) has developed an elegant technique for measuring 17,025 in blood which is capable of detecting concentrations of $0.1 \mu \mathrm{g} . / \mathrm{ml}$., and has examined the blood concentrations of 17,025 in two of our patients. The results indicate that detectable concentrations of 17,025 are found in the blood within 24 hours of injection and that a single injection of $2 \mathrm{~g}$. will persist for at least 7 days.
Table II shows the concentrations in $\mu \mathrm{g}$./ml. of 17,025 in blood and urine of two patients. Patient $\mathrm{A}$ received a dose of $2 \mathrm{~g}$. initially followed by doses of $1 \mathrm{~g}$. 4, 7, and 11 days later. Patient $B$ received an initial injection of $2 \mathrm{~g}$. followed by $1 \mathrm{~g}$. 7 days later.

\section{Clinical Results}

All the patients treated with 17,025 derived some benefit from its administration, and in six of the nine cases treated the clinical result was classified as good or excellent (rapid disappearance of pain and tenderness and diminution in size of bubo).

A striking example of this was that of an Indian who was admitted to hospital with a large non-infiltrated penile sore, a tender painful left inguinal bubo, and a presumptive diagnosis of chancroid, which was confirmed by a positive Itô-Reenstierna skin test. After a

TABLE II

CONCENTRATION OF 17,025 IN BLOOD AND URINE OF TWO PATIENTS ON DIFFERENT DOSAGE SCHEDULES

\begin{tabular}{|c|c|c|c|c|c|c|c|c|c|c|c|c|c|c|c|}
\hline & \multirow{2}{*}{\multicolumn{2}{|c|}{ Patient }} & \multicolumn{13}{|c|}{ Days after Initial Dose $(2 \mathrm{~g})}$. \\
\hline & & & 1 & 2 & 3 & 4 & 5 & 6 & 7 & 8 & 9 & 10 & 11 & 12 & 14 \\
\hline \multirow{3}{*}{ A } & Blood .. & . & 0.7 & 0.6 & 0.8 & 0.4 & $1 \cdot 2$ & $0 \cdot 7$ & $0 \cdot 7$ & $1 \cdot 1$ & 0.9 & - & $0 \cdot 6$ & $1 \cdot 5$ & 一 \\
\hline & Urine $\quad$. & . & $10 \cdot 8$ & $4 \cdot 0$ & $13 \cdot 8$ & $5 \cdot 5$ & $8 \cdot 8$ & $6 \cdot 8$ & $5 \cdot 0$ & $14 \cdot 5$ & $13 \cdot 4$ & - & $16 \cdot 2$ & $6 \cdot 6$ & - \\
\hline & Dosage (g.) & $\cdots$ & & & & 1 & & & 1 & & & & 1 & & \\
\hline \multirow{3}{*}{ B } & Blood $\ldots$ & $\ldots$ & $0 \cdot 1$ & - & $0 \cdot 2$ & - & $0 \cdot 1$ & - & $0 \cdot 3$ & - & - & $<0 \cdot 1$ & - & $0 \cdot 1$ & $0 \cdot 2$ \\
\hline & Urine $\quad$. & . & $5 \cdot 8$ & - & $3 \cdot 0$ & - & $2 \cdot 2$ & - & 0.5 & - & - & $1 \cdot 5$ & - & 0.5 & $1 \cdot 0$ \\
\hline & Dosage (g.) & . & & & & & & & 1 & & & & & & \\
\hline
\end{tabular}


5-day course of sulphathiazole the sore promptly healed but the bubo remained unchanged. The patient was then given a course of streptomycin $0.5 \mathrm{~g}$. twice daily for 5 days, but this had no effect on the inguinal bubo. At this stage the patient's lymphogranuloma inguinale complement-fixation test was reported positive to a titre of 1 in 160 and the Frei test, initially negative, was now found to be positive.

A course of $17,0251 \mathrm{~g}$. twice weekly to a total of $4 \mathrm{~g}$. resulted in rapid and complete resolution of the bubo.

Shortly after being admitted to hospital and before he had received any therapy with 17,025 , this patient developed a "shoulder-girdle neuritis" of the type described by Spillane (1943) which resulted in an almost complete left deltoid palsy. This prolonged his stay in hospital for several months during which time the condition of the inguinal glands remained completely satisfactory.

Five other patients responded equally well, if less dramatically.

The seventh patient had a less satisfactory result; after a fortnight during which $10 \mathrm{~g}$. 17,025 had been administered, there was still a considerable degree of adenitis and periadenitis, but this resolved rapidly after a 10-g. course of terramycin.

The last two patients, both of whom had responded satisfactorily to a course of 17,025 , relapsed after discharge from hospital. This was a surprising development as we had not previously noted relapse in a series of over fifty cases treated by various methods.

Both of these patients presented with large inguinal buboes which were beginning to soften, and one of them also had enlarged glands in the contralateral groin which showed no signs of softening. After $4 \mathrm{~g}$. 17,025 had been given to one and $9 \mathrm{~g}$. to the other, the buboes resolved satisfactorily and the patients were discharged from hospital. Relapse occurred 10 days later in one patient and 15 days later in the other, and both presented with fluctuant inguinal glands requiring urgent aspiration. It is perhaps significant that, in the patient with bilateral buboes, relapse occurred only on the side which had previously shown signs of early softening. In neither case had aspiration been considered necessary during the first admission to hospital, as in our experience small amounts of pus are readily absorbed after sulphonamide or tetracycline therapy, and aspiration is used only where there appears to be a risk of spontaneous rupture.

Both patients were re-treated with 17,025: in one, four further injections of $2 \mathrm{~g}$. produced a satisfactory result, and in the other the response to $1 \mathrm{~g}$. twice weekly for 4 weeks was less satisfactory, but the residual adenitis responded promptly to terramycin.

\section{Summary and Conclusions}

It appears that the drug 17,025 represents a useful addition to the limited number of agents which are effective against lymphogranuloma inguinale. The optimum dosage has yet to be determined but with 2 g. twice weekly no toxic reactions were observed and an initially satisfactory result was obtained in eight of the nine cases treated. The two relapses, however, must not be discounted. To what extent aspiration might have improved the clinical result and prevented subsequent relapse one can only speculate. Because 17,025 lacks anti-bacterial activity it is possible that, in any case with softening, a better clinical result would be obtained if treatment with 17,025 was followed by a short course of one of the tetracyclines to deal with any possible secondary infection. It has previously been observed (Alergant, 1953) that some patients derive most benefit when two different drugs are administered successively, and this may well be true of 17,025 as it is of the tetracyclines and the sulphonamides.

\section{REFERENCES}

Alergant, C. D. (1953). Brit. J. vener. Dis., 29, 218. (1957). Ibid., 33, 47.

Duncan, W. A. M. (1960). Personal communication.

Hurst, E. Weston, and Hull R. (1961). J. med. pharm. Chem., 3, 215.

_, Landquist, J. K., Melvin, P., Peters, J. M., Senior, N., Silk J. A., and Stacey, G. J. (1953). Brit. J. Pharmacol., 8, 297.

Spillane, J. D. (1943). Lancet, 2, 532.

\section{La lymphogranulomatose vénérienne traitée avec le composé 17.025 \\ RÉSUMÉ}

Le composé 17.025 semble augmenter le petit nombre des drogues efficaces contre la lymphogranulomatose vénérienne. La dose optimum n'est pas encore determinée, mais on ne constata pas de réaction toxique et l'on obtint de bons résultats chez 8 des 9 malades qui reçurent une dose de $2 \mathrm{~g}$. deux fois par semaine. Cependant il ne faut pas ignorer les deux rechutes. On ne peut que hazarder une opinion sur l'effet possible de l'aspiration.

Puisque le composé 17.025 n'est pas bactéricide, il se peut qu'on fera mieux, dans les cas qui montrent un amollissement, d'y ajouter une des tétracyclines pour combattre les infections secondaires. L'auteur a déjà constaté que quelques malades guérissent mieux quand on donne deux médicaments, l'un après l'autre, et ceci peut bien être vrai pour le 17.025 comme pour les tétracyclines et les sulfonamides. 